doi http://dx.doi.org/10.18542/rmi.v15i24.10081

Margens: Revista Interdisciplinar | e-ISSN:1982-5374 | V. 15 | N. 24 | Jun, 2021, pp. 253-274.

\title{
DO TAMBOR AO “TRABALHO": ALGUNS ESBOÇOS SOBRE OS ASPECTOS DE EXUS E POMBAGIRAS EM UM TERREIRO DE MINA NO NORDESTE PARAENSE
}

\author{
FROM DRUM TO “WORK”: SOME OUTLINES ABOUT THE ASPECTS OF EXÚS AND \\ POMBAGIRAS IN A MINE TERRESTOR IN NORTHEAST OF PARÁ
}

\author{
Victor Lean do ROSÁRIO (UFPA) ${ }^{1}$ \\ Carla Figueiredo Marinho SALDANHA (UFPA) ${ }^{2}$ (9) (iD) \\ Raquel Oliveira de ABREU (UFPA) ${ }^{3}$ (9) (iD)
}

\begin{abstract}
Resumo: Este artigo tem por objetivo apresentar aspectos referente as simbologias dos Exus e Pombagiras no Terreiro Mina Nagô Cabocla Mariana e Tapinaré das Matas, na cidade de Igarapé-Açu, nordeste paraense. Metodologicamente esta pesquisa foi construída a partir de um esboço etnográfico, tendo a observação participante e o diálogo contínuo com as entidades um ponto fundamental. A partir da exposição dos códigos culturais do "Terreiro" durante o artigo, percebe-se que a título de (in)conclusão, os Exus e Pombagiras ressignificam suas simbologias, (re)criando novas identidades, experiências e (r)existências dentro do corpo umbandista, relacionando e revendo a aproximação entre o mundo sobrenatural e o social.
\end{abstract}

Palavras-chaves: Simbologia. Exus e Pombagiras. Identidades.

\begin{abstract}
This article aims to present aspects referring to the symbols of the Exus and Pombagiras in the Terreiro Mina Nagô Cabocla Mariana and Tapinare das Matas, in the city of Igarapé-Açu, northeast of Pará. Methodologically this research was built from an ethnographic outline, with participant observation and continuous dialogue with the entities a fundamental point. From the exposure of the cultural codes of the "Terreiro" during the article, it is clear that as a (in) conclusion, the Exus and Pombagiras resignify their symbologies, (re) creating new identities, experiences and $(r)$ existences within the umbanda body, relating and reviewing the approximation between the supernatural and the social world.
\end{abstract}

Keywords: Symbology. Exus and Pombagiras. Identities.

\footnotetext{
${ }^{1}$ Mestrando do Programa de Pós-Graduação em Sociologia e Antropologia (PPGSA/UFPA) Membro do grupo de pesquisa PUGNA, etnografia, poder e socialidades. E-mail: victorlattes@gmail.com

${ }^{2}$ Mestre em Antropologia pelo Programa de Pós-Graduação em Sociologia e Antropologia - PPGSA, da Universidade Federal do Pará - UFPA. É membro do Grupo de Pesquisa NOSMULHERES, Grupo de Estudos e Pesquisas com Crianças Infâncias e Juventudes/JUERÊ, na linha de Família, Sexualidades e Gênero. Grupo de Pesquisa em Antropologia Visual e Imagem (VISAGEM), e Grupo de Estudos e Pesquisa Eneida de Moraes - GEPEM, na linha de Gênero e Literatura.E-mail: marinhocarla833@gmail.com

${ }^{3}$ Doutora em Antropologia, pelo PPGSA//UFPA. Avaliadora da Margens: Revista Interdisciplinar do PPGCITI, Revisora da Editora OMINIS SCIENTIA. E-mail: rachelufpa@gmail.com
} 


\section{INTRODUÇÃO}

Este artigo tem por objetivo apresentar alguns aspectos desenvolvidos por Exus e Pombagiras no Terreiro Mina Nagô Cabocla Mariana e Tapinaré das Matas, no município de Igarapé-Açu, nordeste paraense. É importante salientar que as apresentações postas neste trabalho são referentes aos traços, simbologias e especificidades do Exu Tranca Rua e Maria Padilha no Ori ${ }^{4}$ no Pai de Santo da casa, mas que podem sofrer variações de acordo com o contexto e o espaço analisado, pois ao pensar sobre as religiosidades afro-brasileiras, percebemos que as dimensões entre o sobrenatural e o social se misturam, e os pontos convergentes/divergentes são vivenciados de acordo com cada Terreiro (LUCA, NETO, PANTOJA, 2016), por isso que ao discutir sobre as características de Exu e de Pombagira nesta casa de umbanda em questão, apontamos para os aspectos singulares de se "fazer umbanda" no espaço.

Nas pesquisas das ciências humanas, especialmente de cunho antropológico, a metodologia tem um papel fundante na demarcação de objetivos, limites, e que ajuda no entendimento do campo de pesquisa, tornando o exótico em familiar, e o familiar em exótico (DAMATTA, 1981), por isso, ao pensar os moldes metodológicos, a literatura sobre o tema e a criatividade andam de mãos dadas, desenvolvendo o que Deslandes (2009) intitula de artesanato intelectual.

Sendo assim, este artigo tem como metodologia a pesquisa qualitativa, juntamente com a observação participante no Terreiro ${ }^{5}$ analisado, utilizando-se da aproximação e de conversas informais, tecendo "redes de campo" tanto com os/as simpatizantes que frequentam o espaço quanto com as próprias entidades (SILVA, 2015). Por fim, desenvolvo minimamente diálogos com as entidades, especificando Exu Tranca Rua e Maria Padilha, com entrevistas semidirigidas, observando e tomando notas dos gestos, do transe, da dança, dos pontos cantados ${ }^{6}$, das gargalhadas, do barulho e até mesmo do silêncio, tentando compreender o funcionamento dos códigos culturais ali existentes.

Deste modo, o esboço de uma etnografia estará presente durante todo o percurso do artigo, na qual observamos o "Estar lá", no Terreiro com as entidades, e o "Estar aqui", transcrevendo as entrevistas, analisando o caderno de campo, relembrando dos sons, sentidos e usos atribuídos ao

\footnotetext{
${ }^{4}$ Ori é a parte superior da cabeça, onde a mediunidade é concentrada com maior intensidade e também o local onde as energias do médium juntamente com a da entidade se encontram. O Ori é sempre coberto com algum tecido ou chapéu durante os rituais.

${ }^{5}$ O Terreiro Mina Nagô Cabocla Mariana e Tapinaré das Matas foi fundado em 2008, tendo como chefe da casa o "Pai Tadeu", médium de 29 anos que iniciou sua missão aos 07 anos de idade. Atualmente o Terreiro possui 23 filhos/as de santo.

${ }^{6}$ Os pontos (ou doutrinas) são os cânticos que narram ao ritmo do tambor as histórias das entidades, suas moradas, façanhas no mundo e até mesmo o seu nome.
} 
mundo social/simbólico existente no Terreiro (GEERTZ, 2018). E com isso, ao refletir sobre as simbologias e redes culturais neste espaço, outra cultura se torna visível aos olhos do pesquisador (WAGNER, 2010), auxiliando na problematização dos próprios códigos culturais em que estamos inseridos.

Este artigo está dividido em 05 seções. A primeira parte remete-se a um breve aparato histórico do surgimento e (in)compreensão do Orixá Exu ainda na África, até o seu coroamento como a personificação do diabo cristão em terras brasileiras nos terreiros de umbanda; posteriormente, apontaremos as distinções entre o povo da rua (Exu e Pombagira) e outras entidades no panteão umbandista. Em seguida, analisaremos as doutrinas entoadas por Exu Tranca Rua e Maria Padilha no terreiro estudado. Logo após, discutiremos as atribuições corporais dessas entidades, suas posições, gestos e aspectos comportamentais, abrindo caminho para refletir sobre pontos convergentes e divergentes.

$\mathrm{Na}$ quarta seção apresentaremos os "trabalhos" realizados pelo povo da rua, bem como a relação estabelecida (mas não dita) da coletividade sobre a eficácia do ritual. No quinto, descrevemos um dos aspectos ritualísticos referente a luz e não luz no terreiro, na qual discutiremos a importância da luminosidade (ou a falta dela) nas idas e vindas dos Exus e das Pombagiras. Por fim, iremos expor algumas considerações (in)conclusivas sobre as identidades incorporadas por estas entidades, suas ressignificações e manipulações simbólicas, bem como a relação entre a entidade e o/a médium que a recebe, revendo a aproximação entre mundo social e sobrenatural.

Antes de iniciar com as seções, é necessário explicar a você leitor/a que em alguns momentos vamos utilizar a palavra "Exus" e "Pombagiras" no plural, isso significa que as simbologias, características ou instrumentos que são descritos de Exu Tranca Rua ou Maria Padilha também fazem parte da "totalidade" dos códigos culturais do povo da rua específicas do Terreiro estudado, e por isso recorremos ao plural, para explanar que as análises podem ser ampliadas para as outras entidades da mesma falange.

\section{DA ÁFRICA AO TERREIRO: A (IN)COMPREENSÃO DOS EXUS E POMBAGIRAS}

"Exu é o mais sutil e o mais astuto de todos os Orixás. Ele aproveita-se de suas qualidades para provocar mal-entendidos e discussões entre as pessoas ou para preparar-lhes armadilhas. [...] Exu pode também ser muito malvado, se as pessoas se esquecem de homenageá-lo. É necessário, pois, fazer a oferendas a Exu, antes de qualquer outro Orixá. Certa vez, dois amigos de infầncia, que jamais discutiam, esqueceram-se, numa segunda-feira, de fazer-lhes as oferendas devidas. Foram para o campo trabalhar, cada um em uma roça. [...] Exu zangado pela negligência dos 
dois amigos, decidiu preparar-lhes um golpe à sua maneira. Ele colocou sobre a cabeça um boné pontudo que era branco do lado direito e vermelho do lado esquerdo. Depois, seguiu o canteiro, chegando à altura dos dois trabalhadores amigos e, muito educadamente cumprimentou-os. [...] Assim que Exu afastou-se, o homem que trabalhava no campo à direita, falou para o seu companheiro: 'Quem pode ser este personagem de boné branco?' 'Seu chapéu era vermelho', respondeu o homem do campo à esquerda. [...] Cada um dos amigos tinha razão e estava furioso e desconfiado do outro. Irritados, eles agarraram-se e começaram a bater-se até matarem-se a golpes de enxada. Exu estava vingado!" (VERGER, 1997, p.8-10).

A história exposta acima exemplifica bem as características do Orixá Exu, destacando o poder de vingança da entidade quando suas oferendas não são entregues corretamente. O primeiro contato do "homem branco" com esta entidade ocorreu com as missões dos viajantes/comerciantes ao continente africano. Ao se deparar com Exu Fon-Yourubá de figura fálica, considerado desordeiro, irascível e suscetível ao mal, associaram logo ao diabo cristão, modificando seus aspectos e transformando tudo que está vinculado ao Exu se tornar maldade (VERGER, 1999).

A associação entre Exu e o diabo da tradição católica explicita a discussão binária entre bem e mal, ordem e desordem, liberdade e cerceamento (SILVA, 2012) iniciando assim a trajetória destas entidades pelo mundo europeu, até chegar ao panteão afro-brasileiro por meio dos/as negros/as que foram escravizados (BASTIDE, 1978). Este Orixá permaneceu com suas características singulares, sendo deturpados por brancos e respeitados pelos negros.

Entretanto, o apogeu do coroamento de Exu como senhor do inferno ocorreu quando esta entidade foi incorporada no panteão umbandista (PRANDI, 2001), na qual a demonização de Exu cede espaço para "exuzição" do demônio (SILVA, 2012), havendo um processo de assimilação entre estas duas figuras. Na umbanda, esta entidade continua com seus aspectos arruaceiros, mas seu mito de origem e cosmogonias (ELIADE, 1972) sofre modificações, e Exu passa a viver no mundo terreno, possuindo uma vida marginal, subalterna, transgressora, potencializando e externalizando suas experiências, ressignificando as simbologias demônio para (r)existir no mundo social/sobrenatural.

Além disso, as novas configurações de Exu na umbanda dão suporte para uma versão feminina: as Pombagiras. As Pombagiras são entidades emblemáticas do panteão umbandista, possuindo características que remetem a imaginários de antigas cortesãs, "donas de cabaré" de séculos passados. Há também aquelas que possuem um olhar invasivo, que "lêem" a mão, e nos dizem segredos que tememos (ou não) ouvir (BARROS, 2013). Essas características constituem complexidades culturais que renovam combinações entre algo inédito e simultaneamente um resgate ao passado. 
Ademais, as Pombagiras são entidades que no momento de sua vida terrena foram prostitutas, cortesãs, mulheres da nobreza, amantes, aborteiras e até mesmo professoras (BARROS, 2010), apontando que o importante não está na profissão em vidas passadas, mas as características de um feminino transgressor, que possui marcas de desamor e traição, sempre buscando entender a dor de quem a procura, e agindo como mediadora de conflitos amorosos (BIRMAN, 2005).

Com isso, os Exus e as Pombagiras formam a "esquerda" da umbanda, ou seja, as entidades que realizam "trabalhos" que outras entidades se negam a fazer. $\mathrm{Na}$ linha branca estão os/as Caboclos/as, representados indígenas, tendo como aspectos a força e a coragem; há também os/as pretos/as velhos/as, que foram negros/as escravizados, tendo como a bondade e a mansidão suas principais características, e há também os Erês, crianças encantadas que gostam de brincar, comer doces e é representado pela alegria.

Ao se falar dos Exus e Pombagiras, a pureza que existe nas entidades acima não se faz presente, ao contrário, as transgressões em vida terrena são entoadas nos pontos, apontando sempre a rua (em contraposição a casa $)^{7}$ como algo primordial em suas simbologias. Entretanto, não podemos pensar que estas entidades são vítimas do seu destino, ao contrário, foram suas vidas terrenas e "do mundo", consideradas como marginais, que ajudam na construção do imaginário de insubmissão sobre estas entidades. Além disso, a "divisão sobrenatural dos trabalhos" entre Exus e Pombagiras são realizados pelas energias, e não pelo sexo, pois nenhum é maior que outro, são apenas aspectos distintos que se complementam no mundo cultural do povo da rua.

\section{NO BARULHO DO TAMBOR: UMA BREVE ANÁLISE DOS PONTOS DE EXU TRANCA RUA E MARIA PADILHA}

As experiências que obtivemos no trabalho de campo proporcionaram formas de olhar, ouvir e escrever (OLIVEIRA, 2000) muito intensas, modificando as interações com o mundo social. O poder simbólico (BOURDIEU, 1989) demonstra que o mundo umbandista cria, desenvolve e reinventa características muito singulares nas suas práticas, ritos e formas de agir.

No Terreiro Mina Nagô Cabocla Mariana e Tapinaré das Matas, a música, os pontos entoados ao som do tambor pelas entidades, sobretudo os de Exus e Pombagiras, nos instigaram para analisar

\footnotetext{
${ }^{7}$ De acordo com DaMatta (1997), a rua sugere impessoalidade, um domínio semidesconhecido, que possui imprevistos. Ao passo que a casa é um local em que existe um controle das relações sociais. No caso dos Exus e Pombagiras, a rua, e sobretudo as encruzilhadas são apontadas como sua morada.
} 
como que estas simbologias e a instauração de paisagens sonoras (MARQUES, 2012) auxiliam na concepção e percepção do que (ou quem) são os Exu e as Pombagiras. Para isso, tentaremos brevemente analisar algumas doutrinas entoadas por estas duas entidades no Ori do Pai de Santo.

No Terreiro estudado, os pontos são os firmamentos das entidades, e é a partir deste canto que elas são identificadas. Por isso, as músicas entoadas sofrem modificações na letra, na batida, na forma de cantar, etc., de acordo com os códigos sociais/simbólicos do espaço, ou seja, em um terreiro X, o ponto pode ser cantado com um estilo diferente do Terreiro Y. No caso do barracão analisado, o ritmo do tambor é mais rápido, diferente de outras casas que foram visitadas. Em se tratando dos pontos dos Exus e das Pombagiras, sempre há uma maior solenidade e respeito, e é onde as pessoas e entidades presentes cantam com maior fervor. Por fim, é válido explicar que todas as doutrinas citadas foram transcritas dos áudios gravados nas "giras" de Exu que frequentamos.

Com relação ao Exu Tranca Rua, é comum esta entidade iniciar com o seguinte ponto:

O sino da igrejinha faz belém 'blem' 'blom'

O sino da igreja faz belém 'blem' 'blom'

Deu meia noite e o galo já cantou

Seu Tranca Rua que é dono da gira

Oi corre gira que Ogum Mandou ${ }^{8}$

Nesta doutrina conhecida, Tranca Rua se refere ao horário "sagrado" do Povo da rua, a meia noite, que porventura é um momento onde as pessoas de "bem" não devem estar neste espaço, mas ao contrário, se encontram nas suas casas; é neste momento que o sino toca, e o 'dono da gira' está disposto a aparecer. Percebemos a partir deste ponto, que as temáticas apresentadas nas doutrinas são por vezes subversivas, e um dos principais temas que envolvem o Exu está relacionado com a rua, lugar de movimento e de caminhos. O ponto a seguir ilustra muito bem:

Seu Tranca rua
Que nasceu na rua
Se criou na rua
E na rua morreu
$\hat{\text { E tranca rua }}$
Que é dono da rua $(2 \mathrm{x})$
Naquela encruzilhada tem um rei
E esse rei se chama Tranca rua

Nessa música, percebemos que a entidade a todo momento alude o seu nascimento, criação e morte na rua, neste espaço impessoal, povoado de personagens perigosos, onde vivem e se encontram

\footnotetext{
${ }^{8}$ Os pontos que se seguem, foram transcritos a partir das gravações realizadas durante os rituais, compondo o acervo pessoal da pesquisa de campo.
} 
os marginais (DaMATTA, 1997), sendo o Exu um dos principais marginais. Nesse sentido, a rua como morada de Tranca Rua, que conhece muito bem seus caminhos, a entidade se torna o rei da encruzilhada. Esta é umas das principais características do Exu Tranca Rua: ser considerado rei, príncipe, ou dono da rua, conhecedor dos caminhos, podendo "abrir" ou "fechar" de acordo com a necessidade do/a cliente que procura seus atendimentos.

Em relação aos "trabalhos” envolvendo Tranca Rua, uma doutrina entoada por ele (e também utilizadas por Pombagiras) diz respeito ao caminho longo a ser percorrido, um caminho "alagado" (referente às dificuldades encontradas para obter êxito nos "trabalhos"), mas que demonstra que a sina destas entidades é "trabalhar", ou seja, apontar as direções corretas para os/as seus/suas clientes. É interessante perceber que nesta doutrina faz referência ao diabo cristão, aproximando Exu do satanás. Segue o ponto:

\author{
Caminho longo \\ É um caminho alagado $(2 \mathrm{x})$ \\ E por esse caminho \\ Só quem anda é o diabo \\ Trabalha diabo \\ Trabalha diabo \\ Trabalha diabo, sua vida é trabalhar
}

Nos pontos entoados por Maria Padilha, as referências às encruzilhadas também aparecem costumeiramente. Além disso, há frases que falam sobre rosas, e a composição da família das "Marias", bem como a referência ao diabo cristão pela caricatura de Lúcifer. É pertinente salientar que as palavras e/ou frases referentes ao diabo cristão são construções do imaginário subversivo, ou seja, reivindicam para si a identidades subalternizadas construídas sobre suas simbologias, como sugere o ponto abaixo.

\author{
Foi uma rosa \\ Que eu encontrei na encruzilhada \\ Foi uma rosa \\ Que eu plantei no meu jardim \\ Maria Padilha \\ Maria Mulher \\ Maria Padilha \\ A mulher de lucifer
}

Neste aspecto, conseguimos perceber que ao entoar estas frases, juntamente com o rufar do tambor, e as forças rituais que rodeiam cada ponto, as identidades são ressignificadas, simbologias reconstruídas, e relações sociais são experimentadas a partir das marginalidades dos Exus e das Pombagiras. Desse modo, é necessário percebermos que a ritualização musical não pode ser entendida 
apenas pelos seus aspectos de letra e estética, mas também como uma forma de comunicação com códigos próprios, estando ligada ao dançar (PINTO, 2001) e a performance atribuída pelas entidades.

Com isso, a próxima doutrina entoada por Maria Padilha faz alusão ao luar da noite, ao respeito que precisa ter com a entidade, juntamente com a relação atribuída com Tranca Rua, que não é de submissão, mas de vínculos construídos ao longo do tempo. A doutrina fala também sobre sangue derramado, e sobre a morada de Maria Padilha, que é no portão. Isso sugere a volatilidade, a mudança e as andanças de Maria Padilha.

Ô luar, ô luar, ô luar (ô luar)
Eu sou filha da rua (ô luar)
Mas com mexer com a Padilha
Vai prestar conta com Exu e Tranca Rua
Eu vejo sangue derramado (ô luar)
Nesse grande frio e chão (ô luar)
Mas onde mora Maria Padilha
A ela mora no portão

Se fôssemos nos deter apenas nas doutrinas, seria um material suficiente para realizar outro artigo. Entretanto, salientamos que os pontos analisados acima sugerem características identificadores das singularidades destas entidades, haja vista que as músicas estão conectadas com outras expressões culturais do terreiro. Ademais, os pontos são manifestações simbólicas que sugerem a crença nas entidades ali cultuadas, apontam uma existência específica, e que precisa ser analisada dentro do seu próprio contexto (PINTO, 2001). Por isso, ao cantar e dançar estas doutrinas, Exu Tranca Rua e Maria Padilha também se transformam naquilo que eles/as entoam.

A seguir, tentaremos minimamente analisar o processo performático das entidades no corpo do médium, tentando observar aspectos característicos destas entidades na corporeidade e comportamento, traçando aspectos singulares que possibilitam pensar a identidade de Exus e Pombagiras.

\section{RELIGIOSIDADE E CORPO: RELAÇÕES E PERFORMANCES}

As configurações antropológicas do "Estar lá", seja em uma pesquisa transoceânica, seja no trabalho de campo na cidade em que reside, faz com que o/a pesquisador/a passe por processos liminares (DaMATTA, 1981), redescobrindo formas outras de se portar no mundo. O pesquisador ao ter contato com o outro, consegue como ninguém entender a diferença.

No mundo umbandista, onde a performance individual e coletiva são pilares centrais para a construção dos rituais e da eficácia do "trabalho", o corpo mediúnico se torna uma característica de 
análise interessante de observação, pois a relação estabelecida entre o médium que "cede" seu corpo para a entidade, se tornando seu "cavalo", , reinventa formas comportamentais que criam suportes para a explicação antropológica.

Em relação aos estudos de corporeidade, Mauss (2003) analisou as técnicas corporais, observando que as corporalidades possuem especificidades, haja vista que cada sociedade desenvolveu formas de educar o corpo, e que os hábitos (nadar, caminhar, posição da mão, etc.) variam de acordo com os aspectos culturais. Ainda segundo o autor, o corpo é o primeiro instrumento natural do homem, e que as técnicas são eficazes devido à tradição (MAUSS, 2003). Neste sentido, as noções de Mauss sobre técnicas corporais auxiliam na explicação da corporeidade e da performance dos Exus e Pombagiras em relação ao corpo do médium.

Desse modo, pensar a corporeidade na performance implica uma ideia de "liminaridade", pois é pelos nossos corpos que experimentamos o mundo (PEREIRA, 2014), e por isso, desde a dança, ao momento da incorporação, a possessão da entidade até o momento de despedida, sentimos a dinâmica corpórea dos médiuns que transitam entre os espaços simbólicos, para que os "trabalhos" realizados possam ter a maior eficácia possível. Sendo assim, a partir de agora analisaremos a atuação corporal dos Exu Tranca Rua e Pombagira Maria Padilha em “cima” do Pai de Santo. É válido salientar que embora apenas duas entidades sejam analisadas, as características corporais não possuem tantas variações entre os/as outros/as médiuns e suas entidades no contexto do Terreiro estudado.

No caso de Exu Tranca Rua em "cima" do Pai Tadeu, as singularidades corporais são explícitas no momento de possessão. As entidades (sejam de qualquer falange) são convidadas a se fazerem presente pela abertura da "gira"10, onde são entoados pontos que "chamam" os caboclos para “descer" no corpo do médium. No caso do povo da rua, os pontos são entoados à 00h00min (com exceção de "trabalhos" urgentes).

No momento da "descida" de Exu Tranca Rua, o corpo do médium é chacoalhado veementemente, e quando a entidade "arreia"11 definitivamente, a postura corporal fica mais mecanizada. O seu primeiro gesto é retirar a camisa, e o tronco é curvado para baixo, as mãos ficam retorcidas, e transparece muito esforço da entidade ao andar, dando a impressão que existe no corpo algum peso. Esta entidade evita movimentos bruscos, preferindo falar ao pé do ouvido do Ogã ou da Ekedy. A gargalhada é uma das suas formas de identificação.

\footnotetext{
9 Termo utilizado entre os umbandistas que explica a relação de possessão da entidade sobre o/a médium.

${ }^{10}$ A gira é um momento ritualístico no qual os médiuns saúdam os Orixás e os/as Caboclos/as, chamando-os para se apoderar do corpo do médium. O ápice central está na conexão consensual entre a entidade e o médium presente.

${ }^{11}$ Quando a entidade passa a controlar o corpo do médium receptor.
} 
Diferentemente das outras entidades, Tranca Rua não se levanta e cumprimenta os/as clientes da casa e os/as convidados, ao contrário, são as pessoas que vão até ele para tomar benção ou algum conselho. Geralmente, Tranca Rua fica sentado em um banco pequeno frente ao tambor, fumando um cigarro ou charuto e bebendo preferencialmente a "sangria" 12 . Caso haja algum "trabalho" na casa, o Exu doutrina durante a realização dos "fundamentos", e posteriormente permite que as outras entidades (que componham a falange da rua) possam doutrinar.

Desde a sua chegada até o momento da partida, Tranca Rua sempre produz movimento rente ao chão, possuindo uma gestualidade mais mecânica e com poucos movimentos. David Le Breton (2007) profere que os gestos corporais e faciais incorporam diferentes significados. Somando a isso, Tranca Rua possui poucas roupas e acessórios para se paramentar. Esta entidade usa apenas um chapéu de couro preto simples, sem nenhum tipo de decoração, e um tecido de seda preto, que usa como "capa", juntamente com a guia vermelho e preto ${ }^{13}$. O visual de Tranca Rua é singular, pontuando seus aspectos sociais e simbólicos.

Contrariamente aos Exus, a Pomba Maria Padilha se apresenta com posturas mais sensuais, evidenciando no corpo a alegria e o poder. Esta entidade se movimenta por todo o salão, cantando e dançando seus pontos, e cumprimentando as pessoas presente. Na maioria das vezes, usa roupas brilhantes com paetê (vermelho e preto), bem como uma "espada"14 também vermelha e preta usada para cobrir a cabeça. Dependendo do ritual, utiliza pulseiras e outras bijuterias e um véu preto.

A Maria Padilha não se contenta com a estática, prefere está a todo momento transitando entre os locais do barracão (e inclusive fora dele), sensualizando no andar, possuindo uma voz mais afeminada no corpo do pai de santo. Ao gargalhar, é perceptível ser mais aguda e estridente do que Exu, transportando seu tronco para cima, como se buscasse o céu. Os movimentos graciosos, o perfume que exala por todo o local, e o fascínio na dança são algumas das singularidades da Maria Padilha, pois seu comportamento lembra uma cortesã que outrora foi extremamente rica.

De acordo com Le Breton (2007, p.30)

De uma sociedade para outra, a caracterização da relação do homem com o corpo e a definição dos constituintes da carne dos indivíduos são dados culturais cuja variabilidade é infinita. [...] $\mathrm{O}$ homem e o corpo são indissociáveis e, nas representações coletivas, os componentes da carne são misturados ao cosmo, a natureza, aos outros.

\footnotetext{
12 Termo referente ao vinho tinto.

13 Que dependendo do tipo de "trabalho" a ser realizado, pode ser posicionado de formas distintas.

${ }^{14}$ É um tecido que cobre o Ori.
} 
Deste modo, percebemos que a relação entre a entidade e o corpo do pai de santo sugere que para além de atos individuais, existem também construções coletivas, pois o público não é um mero receptor, mas também interage com os gestos, falas, comportamentos, xingamentos e até o mesmo o silêncio das entidades. Dentro do terreiro, as relações entre o sobrenatural e o social são constantes.

Por isso, o paradigma da corporeidade (CSORDAS, 2008) é tão necessário nas análises simbólica dos Exus e das Pombagiras, pois sugerem relações negociáveis e performáticas entre o sobrenatural (as entidades) e o social (o médium e o público presente), afinal, "os corpos ganham sentido socialmente" (LOURO, 2000, p.6). Com isso, o corpo mediúnico (re)age de acordo com a conexão das entidades, e é pelos "trabalhos" realizados que ocorre esta manifestação singular, e por essa razão, dedicamos o próximo tópico para analisar os “trabalhos” de Exu Tranca Rua e Maria Padilha.

\section{"TRABALHA DIABO"15: CONCEPÇÕES, CARACTERÍSTICAS, SIGNIFICADOS}

Um dos aspectos no mundo umbandista são os "trabalhos" realizados, haja vista que é por este fenômeno que o panteão se desenvolve e os terreiros são reconhecidos. De acordo com Peter Fry (1982), é pelo Pai de santo que se cria um centro de distribuições relacionados aos "trabalhos", pois “[é] onde os serviços mágicos são trocados por dinheiro com os clientes ricos” (FRY, 1982, p.75). Embora as relações de troca sejam constantes, não podemos deixar de observar o processo de caridade referente à umbanda. Como já presenciamos inúmeras vezes no terreiro, pessoas que não podem pagar pelos serviços, sendo atendido, reforçando a ideia de bondade e empatia desenvolvida no panteão umbandista desde os seus primórdios.

No Terreiro Mina Nagô Cabocla Mariana e Tapinaré das Matas, esta lógica se repete. De acordo com o Pai de santo, os "trabalhos" são realizados de segunda a sexta, com agendamentos via redes sociais, ligação, e se for caso de urgência, o atendimento pode acontecer sem hora marcada. Por se tratar de um assunto muito veemente na umbanda, Brito (2019) realiza um ensaio etnográfico sobre os "trabalhos" de cura no terreiro, através da medicina popular. Em sua pesquisa, o autor aponta que os 'trabalhos' realizados não seguem uma data ou dia específico para serem realizados, pois dependem da demanda dos/as clientes (BRITO, 2019).

Em se tratando dos "trabalhos" realizados pelos Exus e pelas Pombagiras, existe um estigma construído socialmente, devido ao ponto de vista moral instituído sobre o bem e o mal. Para os Exus

\footnotetext{
${ }^{15}$ Faz referência a um dos pontos entoados pelos Exus ou Pombagiras.
} 
Pombagiras, o bem e o mal são faces da mesma moeda (PRANDI, 2010), podendo e devendo atuar nos dois lados. Estas entidades são a ponte relacional entre a bondade a maldade. Neste caso, não são as entidades o antro de maldade, mas elas possuem a capacidade "trabalharem" na "esquerda", isto é, as pessoas procuram seus serviços visando malefícios, e o povo da rua atende. Os Exus e as Pombagiras aceitam "trabalhos" sem pestanejar (PRANDI, 2001; CRUZ, 2013), diferentemente das outras entidades.

Deste modo, no Terreiro estudado os "trabalhos" em que os Exus e/ou Pombagiras ficam encarregados podem variar de acordo com a necessidade do cliente, bem como os recursos financeiros disponíveis, pois dependendo do que será realizado, haverá gastos com material, tais como: velas específicas, bebidas, entre outros. A título de exemplo, de acordo com as próprias entidades, um “trabalho" para amarração ${ }^{16}$ no Terreiro Mina Nagô Cabocla Mariana e Tapinaré das Matas, pode variar os valores de R \$ 7.00 à R \$ 1.000, somando com o material, pagamento do abataseiro ${ }^{17}$ etc.

Além disso, os "trabalhos" realizados por estas entidades ocorrem em sua maioria pela madrugada, iniciando com o toque do tambor por volta de 21 horas, se estendendo até a madrugada. Nestes casos, quem realiza o "Trabalho" é o Exu e/ou Pombagira (ou os dois, em revezamento) em "cima" do Pai de santo, possuindo horas específicas para serem realizados determinados rituais, como o acender das velas, os murmúrios inaudíveis, as orações entrecortadas, as conversas com os clientes, etc. Todo o ritual do "trabalho" possui um significado (ABREU \& ROSÁRIO, 2020).

Conforme os escritos de Mauss (2003) o rito mágico é aquele que acontece a partir do privado, do secreto e do misterioso, sempre com buscas tendenciosas ao proibido, e que o mágico é alguém com poderes inimagináveis, emanando magia de seus gestos, modo de falar e até mesmo o toque (MAUSS, 2003). Com isso, os "trabalhos" realizados por estas entidades são de vital importância para a descrição das próprias entidades. E desse modo, em uma conversa com Exu Tranca Rua, indagado sobre os "trabalhos" realizados, este me respondeu:

Pesquisador: Quais são os principais "trabalhos" que o Exu realiza em "cima” do seu filho?

Exu: Em "cima" do filho, de cura, de prosperidade, de abrimento de caminho, de estabilidade financeira, a gente raramente (mais de 12 anos) que a gente não faz trabalho 'pra' tipo, botar nomes 'pra' fazer mal, a gente faz mais o bem.

Pesquisador: E a Maria Padilha?

Exu: A gente 'trabalha' juntos, entendeu? Tem 'trabalhos' que ela vem, tem 'trabalhos' que não venho. Quando ela vem, eu não venho. 'Trabalhos' são justamente pela força, ela tem a dela, eu tenho a minha, então quando a gente pega

\footnotetext{
${ }^{16}$ Consiste em um processo mágico para atrair ou "trazer de volta" o conjugue de forma imediata.

${ }^{17}$ Pessoa responsável por tocar o tambor.
} 
o "cavalo" que nesse "trabalho" deixa o corpo do filho muito "moído", no sentido de fraco, então há trabalhos que a gente necessita vim, ou seja, é quando a gente pede uma preparação para o filho, para ele não se desgastar espiritualmente, materialmente, tipo, manter relação [sexual], não comer com exagero, ter todo aqueles cuidados 'pra' na hora, na nossa reação não causar problemas mais a ele, porque a nossa força já vai sugar ele entendeu? Já vai sugar as energias dele, então a gente tem e deixa dito 'pra' fazer, ter esse cuidado de fazer o preparo, pra que possa equilibrar o corpo do filho, a mente dele, que ele possa ter um bom êxito no final. (Tranca Rua, 20/01/2020).

Esta transcrição da entrevista tem inúmeros aspectos pertinentes para análise. O primeiro ponto a ser abordado diz respeito aos "trabalhos" realizados pelo Exu Tranca Rua, que são referentes a cura, prosperidade e "abrimento" de caminho. Estas características demonstram que Exu, em "cima" do Pai de Santo, evita realizar atividades para a maldade, transformando sua força, suas energias para outros tipos de serviços. Entretanto, vale salientar que a entidade enfatiza que "em cima" deste médium não trabalha na linha da maldade, na qual subentendemos que estes "trabalhos" podem acontecer com outros médiuns.

Outro aspecto destacado é o comentário sobre a Maria Padilha e a força das entidades. De acordo com Exu, cada entidade possui sua força para "trabalhar", apontando no mesmo raciocínio sobre a não hierarquização e/ou subordinação entre o feminino e o masculino (BARROS \& BAIRRÃO, 2015), e que a “divisão sobrenatural dos trabalhos" é desenvolvida pelas diferenças nas vibrações e energias destas entidades. Sendo assim, nem Tranca Rua e nem Maria Padilha possuem mais força para “trabalhar”, mas existe uma divisão que organiza as energias, dependendo do serviço a ser realizado.

Outra característica a ser enfatizado na fala de Tranca Rua, é sobre a "preparação do fillho" em relação à possessão do Exu ou da Pombagira. Para isto, o médium precisa seguir alguns cuidados, tais como: não manter relação sexual (o tempo varia de acordo com intensidade da atividade), não comer exageradamente, dentre outros. Sobre a proibição do relacionamento sexual antes dos rituais se deve ao fato da impureza do corpo para receber a entidade, haja vista que a materialidade do médium é um receptáculo, e precisa estar "limpo" para se aproximar do sagrado (DOUGLAS, 2012).

E com relação a comida exacerbada, a explicação dada é que se o médium estiver muito cheio no momento da incorporação, seu corpo pode rejeitar o alimento, podendo ter ânsias de vômito, dentre outros problemas. Estes cuidados a serem seguidos são para a própria proteção do médium, pois o próprio Tranca Rua admite que a energia do povo da rua 'suga' as forças dos sujeitos que o recebem, e por isso deve haver um equilíbrio entre a energia espiritual e material. O que nos chama atenção nesta fala é sobre o cuidado que as entidades possuem em relação ao seu "cavalo". 
No caso das Pombagiras, os "trabalhos" mais comuns são de amarração citado anteriormente. Ademais, "trabalhos" para a prosperidade em algum empreendimento também é muito realizado por esta entidade, juntamente para afastar forças negativas, a partir de banhos e a ritualização com velas específicas. No que diz respeito às velas, o significado e a função podem variar de acordo com o ritual realizado, bem como a disponibilidade financeira do/a cliente, pois se trata de um material de alto custo financeiro. As velas mais comuns são: "Vira-pensamento", "amansa corno", "Cérebro", "Anjo de guarda", "Alma gêmea", "União", "Sete dias", etc. Os significados das velas citadas em sua maioria são de "trabalhos" para amarração e para abrir caminhos, com exceção da vela "Sete dias", que tem como função o fortalecimento espiritual do médium com as entidades, a partir da chama acesa.

Foto 1: Velas utilizadas no "trabalho" do povo da Rua

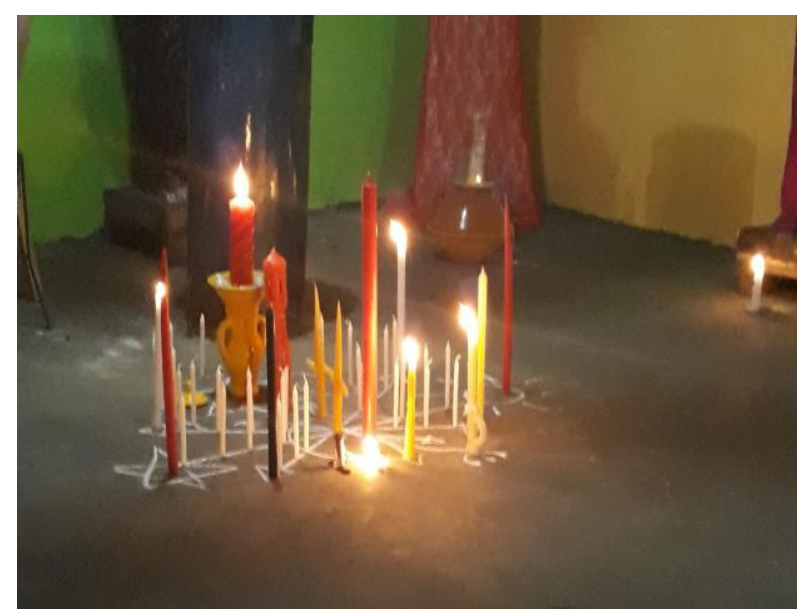

Fonte: LEAN, Pesquisa de campo, 2019.

$\mathrm{Na}$ imagem acima, observamos a variedade de cores, formatos e tamanhos das velas, cada uma com sua energia específica para o "trabalho" que está sendo realizado. No caso das velas brancas, tem como propósito a paz, as velas vermelhas trazem as energias da paixão e da força, já as amarelas têm como significado o movimento e o desespero, e a vela preta remete a força dos Exus e Pombagiras. Além disso, conseguimos visualizar que as velas estão dispostas em cima de um desenho feito a giz no chão. Estas figuras são os pontos riscados, na qual cada Exu e Pombagira tem o seu, e que de acordo com Maria Padilha, representam os "caminhos" a serem seguidos no ritual, sendo a figura modificada a cada "gira".

Outro aspecto essencial que compõe os símbolos dos "trabalhos" do povo da rua é o tambor. Sobre isso, Campos (2014) aponta que é "o som dos atabaques que vai buscar as energias boas, os orixás, os voduns, pois assim como a palavra que tem o poder de animar a vida e colocar o movimento em axé, é o som que conduz e proporciona o axé” (CAMPOS, 2014, p. 17). Deste modo, a junção de 
todo o aparato utilizado nos "trabalhos", as entidades, os dizeres, as energias que compõe o ritual e o som do tambor, constituem símbolos energizantes do panteão umbandista, e dos Exus e Pombagiras.

$\mathrm{Na}$ imagem abaixo, é possível visualizar os códigos culturais juntos, pois Exu Tranca Rua em “cima" do Pai de Santo está acendendo algumas velas em cores de vermelho, amarelo e branco, as luzes estão apagadas, e atrás da entidade está o tambor, que pulsa veementemente ao som da doutrina de Tranca Rua.

Foto 2: Exu Tranca Rua acendendo velas no "trabalho"

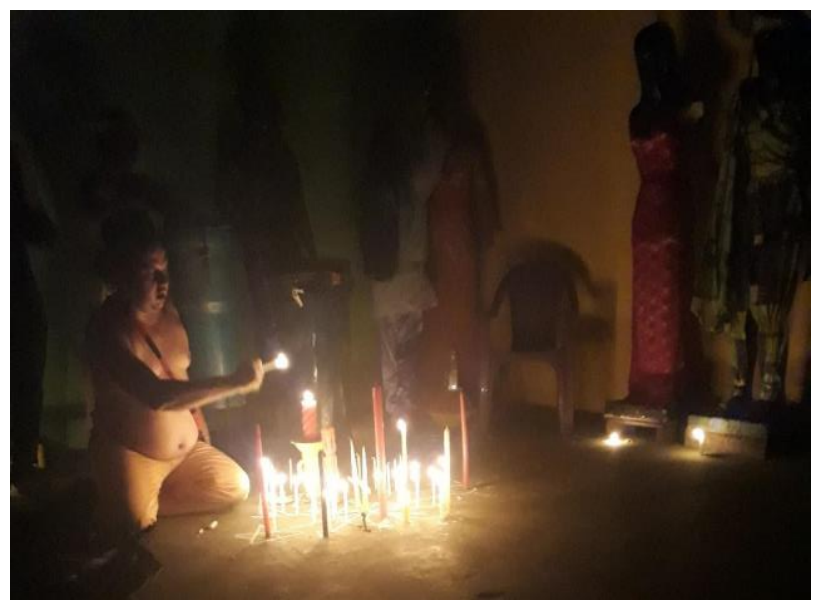

Fonte: LEAN, Pesquisa de campo, 2019.

O dinamismo simbólico existente nos "trabalhos" se aproxima dos escritos de Van Gennep (2011) acerca dos ritos de passagem. Os ritos de passagem constituem três fases: a separação de uma determinada posição social, a margem (ou limem), que diz respeito ao posicionamento ambíguo, e a agregação a um outro grupo social/simbólico (VAN GENNEP, 2011). Nos detemos especialmente no conceito de liminaridade desenvolvido por Turner (1974). Segundo o autor, "as entidades liminares não se situam aqui nem lá: estão no meio e entre as posições atribuídas e ordenadas pela lei, costumes, convenções e cerimonial" (TURNER, 1974, p.117). Desse modo, ao realizar os "trabalhos" de cura, mas também de amarração, as entidades flutuam entre caminhos que não são fixos, e, portanto, liminares.

Entretanto, ainda sobre os ritos de passagem e a liminaridade na concepção "turneriana", o autor profere que os seres liminares, são passivos e humildes, na qual são reduzidos a praticamente nada, para renascerem em outro status social/simbólico (TURNER, 1974). Esta concepção não se aproxima da dinâmica dos Exus e das Pombagiras, pois estas entidades, tanto na realização dos seus "trabalhos", quanto em qualquer outro aspecto, não se subordinam tão facilmente a qualquer um. 
Por isso, recorremos novamente ao trabalho de Mauss (2003), no ensaio sobre a magia. Ao explanar suas concepções sobre os ritos mágicos, o autor aponta que a magia ocorre no mundo proibido, sendo realizado porventura na alta madrugada, onde são ritualizados seus segredos. Ainda nesta linha de raciocínio.

Os ritos mágicos, e a magia como um todo, são, em primeiro lugar, fatos de tradição. Atos que não se repetem não são mágicos. Atos em cuja eficácia o grupo não crê,, não são mágicos. A forma dos ritos é eminentemente transmissível e é sancionada pela opinião (MAUSS, 2003, pp. 55-56. (grifos meus)

De acordo com a assertiva acima, a eficácia dos atos mágicos precisa da crença e da aprovação do público, neste caso, dos/as clientes que procuram as entidades para a realização dos serviços, e as pessoas presentes que assistem e participam da eficácia simbólica. Sendo assim, estas prerrogativas se aproximam - embora com ressalvas - do pensamento de Lévi-Strauss (2008) sobre o feiticeiro e a sua magia. Para ele, a eficácia do ritual precisa de três partes que se complementam: A primeira é a crença no mágico ( $\mathrm{O}$ médium e suas entidades), em seguida a crença de quem procura os serviços e os "trabalhos", e a terceira é a confiança da opinião coletiva sobre os atos mágicos.

Percebemos, portanto, que as atividades dos Exus e das Pombagiras, embora envoltos de uma amálgama de símbolos, gestos e características ritualísticas, um dos traços destes rituais, é que precisam da aprovação coletiva para sua força e energia atuarem nos serviços prestados. Por isso, tanto Exu Tranca Rua, quanto Maria Padilha, constroem uma identidade de herói trickster ${ }^{18}$ (TRINDADE, 1985), sempre tendo como característica o movimento e a ponte entre o bem e o mal como parte principal das suas singularidades.

Com isso, para finalizar esta seção, nos inclinamos ao pensamento de Evans-Pritchard (2005) sobre a bruxaria entre os Azande. Para o autor, a bruxaria está entrelaçada no cotidiano, fazendo parte do mundo ordinário dos Zande (EVANS-PRITCHARD, 2005). Retirando a nomenclatura de "bruxaria", que não se adequa a este contexto, os "trabalhos" realizados no plano sobrenatural, através dos Exus e as Pombagiras juntamente por intermédio do corpo do Pai de Santo, se constituem como trabalho cotidiano do médium, que consistiria em um trabalho assalariado, pois para o Pai Tadeu, o seu trabalho é o mesmo das entidades.

Observamos que a composição para a realização dos "trabalhos", bem como sua eficácia dependem de inúmeras simbolizações construídas no decorrer do tempo e também do espaço, e uma

\footnotetext{
${ }^{18}$ De acordo com Trindade (1985), o herói trickster é a espécie de um anti-herói, que não segue as regras socialmente impostas.
} 
delas diz respeito a luminosidade (ou a falta dela) no ambiente, criando contrastes entre o claro e o escuro. E é por isso que no próximo Subtópico analisaremos a influência da luz ou não no terreiro, como construto social/simbólico do povo da rua.

\section{LUZ E NÃO LUZ NO TERREIRO: ALGUMAS IMPRESSÕES}

Depois de analisar os "trabalhos" dos Exus e das Pombagiras, não podemos deixar de observar o papel da luz (ou não luz) na composição da eficácia simbólica (LÉVI-STRAUSS, 2008) em relação aos "trabalhos" realizados.

Nos "trabalhos" dos Exus e das Pombagiras, as luzes são apagadas antes de iniciar a "gira", e a iluminação do terreiro fica por conta das velas que estão (ou serão) acesas durante o ritual, e caso o céu não esteja nublado, a luminosidade da lua também irradia o local. Como já foi dito acima, a lua possui um funcionamento simbólico da escuridão, tal qual fica evidente nos pontos entoados pelas entidades.

Com a pouca iluminação, o ambiente é reinventado por novos ares e energias, trazendo consigo a seriedade e o respeito pelas entidades que se fazem presente, que trabalham na transição entre a luz e a não luz. A pouca claridade do ambiente, somando com as gargalhadas e performances das entidades, o terreiro é transformado pelos tons simbológicos sepulcrais, sendo evidenciadas imagens a meia luz que captamos.

Com isso, as cores dos Exus e Pombagiras ficam mais evidentes. O vermelho e preto inunda o local, juntamente com as chamas das velas, expondo que a sombra, a pouca claridade, as cores fortes, o fogo, fazem parte das identidades que os Exus e Pombagiras recriam para si mesmos e para quem os assiste. Perante isso, havia a indagação se conseguiríamos fotografar estes momentos singulares, haja vista que as fotografias fazem parte de uma "cultura visual" (ECKERT \& ROCHA, 2001), sendo muito utilizadas por antropólogos para pensar e fazer a antropologia (NOVAES, 2009).

A questão ética de respeitar o espaço sagrado do outro me rodeava, por isso a fotografia se tornou um "tabu" para mim, haja vista que sentia invadir um espaço a qual não pertencia, isto é, diferente e que não fazia parte da minha realidade, e mesmo depois de receber autorização do pai de santo e das próprias entidades, o receio continuou em relação às fotografias.

Entretanto, apresentamos na imagem abaixo um "trabalho" sendo realizado por Maria Padilha em frente à casa de Exu, onde a pouca luminosidade, as velas ritualísticas de cores vermelha e amarelos, os papéis debaixo (com os nomes das pessoas para quem o "trabalho" está sendo realizado), 
e a pituca de cigarro na mão da Padilha simbolizam este ambiente mais mórbido, onde ao luar da noite os segredos da magia acontecem.

Foto 3: Maria Padilha acendendo velas em frente à casa de Exu

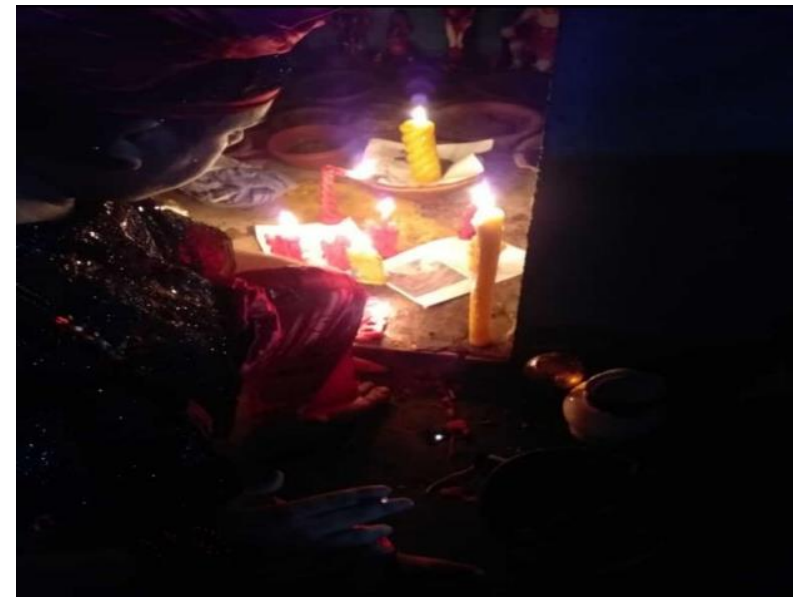

Fonte: Acervo do Terreiro, 2019

Para além das concepções teóricas sobre a luminosidade e a sua ausência, Exu Tranca Rua nos explicou em uma conversa no dia 20/01/2020. A própria entidade pergunta:

Exu: Você já procurou saber o significado da luz apagada e da luz acesa? Pesquisador: Eu nunca tinha pensado nisso.

Exu: A luz apagada é a concentração, a gente puxa mais energia, o médium se sente mais concentrado espiritualmente, para fazer os pedidos, e é o momento da centralização dos espíritos, tanto das trevas, quanto da luz, conseguem ser diferenciadas. É um momento de energias que a gente, a força ela vem maior, a energia vem melhor, entendeu? Para ser diferenciado as positividades e as negatividades. Ah (sic) Seu Tranca, muitos têm essa 'coisa' sobre a luz apagada, e sobre a luz acesa. Diz que luzes apagadas chamam coisas ruins. Meu filho (se referindo ao seu Tadeu) ele acha assim, mas é totalmente diferente, entendeu? Seu Tadeu não dorme no escuro. Mas a gente consegue sugar toda a negatividade dele quando a luz está apagada (Seu Tranca Rua, 20/01/2010).

A concepção apresentada pela entidade sugere que a pouca luminosidade do ambiente auxilia para que as energias do ritual mágico possam ser centralizadas, onde a energia vem "melhor", de acordo com a própria entidade. Aponta também que com as luzes apagadas, as energias podem ser diferenciadas entre as que são "positivas" e "negativas", como se fosse um catalisador das simbologias, e consequentemente auxiliasse na eficácia dos "trabalhos" realizados.

Um aspecto interessante desta fala, é que a entidade demonstra que o próprio médium entende errado esta simbologia, acreditando que a não luz "chama" coisas ruins. Percebemos com isso, que esta relação dual entre luz e não luz, claro e escuro, dia e noite sugere movimentos que são próprios 
do ritual, que não fazem parte das cifras culturais da realidade a qual nos habituamos a ter como referência, tal seja, a luz. O "nós" e "não nós” pulsa nesta relação dual (GEERTZ, 2018). Além disso, percebemos também que os Exus e as Pombagiras não são apenas da escuridão, mas ao contrário, transitam entre estes caminhos, dependendo do "trabalho" a ser realizado.

A partir de esboços etnográfico, apontamos algumas características de Exu e Pombagira no contexto de um Terreiro no nordeste paraense, descrevendo relações construídas nas convenções dinâmicas do espaço, na qual as negociações sobre a eficácia dos "trabalhos", das simbologias e das próprias construções sociais envolventes da religião.

\section{CONSIDERAÇÕES FINAIS: IDENTIDADES DOS EXUS E POMBAGIRAS}

As análises realizadas sobre os pontos entoados, as performances corporais constituídas, os "trabalhos" realizados e a luminosidade do local indicam caminhos sobre certos aspectos de identidades dos Exus e Pombagiras. Estas entidades são fundantes no corpo social da umbanda, e possuem características específicas que desafiam ordens estabelecidas institucionalmente por outras religiões, pois o medo da crença popular sobre o povo da rua não é motivo de estigma, mas como ponte (r)existência de seu corpo simbólico.

Por isso que ao incorporar as potencialidades sociais sugeridas como arquétipo do mal e referentes ao diabo cristão, Exus, Pombagiras e também os médiuns realizam uma manipulação simbólica (FRY, 1982), ou sejam, ressignificam e adaptam de acordo com as necessidades do ritual, e é por isso que o reino destas entidades está sempre à margem, no trânsito entre o bem e o mal, sem lugar fixo, mas na dinâmica do cotidiano.

Não podemos nos enganar, quando descrevemos simbologias de uma entidade, tal como realizada aqui, estamos também explicando as características sociais dos médiuns que vivem neste meio. Deste modo, ao pensar nas identidades fronteiriças (LOURO, 2000) dos Exus e Pombagiras, as fronteiras dos sujeitos umbandistas também ficam evidentes.

E com isso, ao refletir sobre estas entidades e todos os códigos culturais que envolvem o corpo sobrenatural/social, ruminamos conjuntamente no mundo dos personagens tornam esses rituais possíveis, que são também condenados ao mundo diabólico, como bodes expiatórios (LAGES, 2003), mas se utilizam da negação das suas identidades, como forma emancipadora. 


\section{REFERÊNCIAS}

ABREU, Rachel de Oliveira. \& ROSÁRIO, Victor Lean do. "Seu Tranca Rua que é dono da gira": Uma análise antropológica sobre Exus e Pombagiras no Terreiro Mina Nagô Cabocla Mariana e Tapinaré das Matas, nordeste paraense. Religare, v.17, n. 2, dezembro de 2020, pp. 537-562.

BARROS, Mariana Leal de. "Os deuses não ficarão escandalizados": ascendência e reminiscências de femininos subversivos no sagrado. Estudos Feministas, Florianópolis, 21(2): 336, maio-agosto, 2013, pp.509-534.

Pombagiras. Tese (Doutorado em Psicologia). Universidade de São Paulo. Ribeirão Preto: 2010.

BARROS, Mariana Leal de. \& BAIRRÃO, José Francisco Miguel Henriques. Performances de gênero na umbanda: a pombagira como interpretação afro-brasileira de "mulher"? Rev. Int. Estu. Bras., Brasil, n.62, dez., 2015, pp.126-145.

BASTIDE, Roger. O candomblé da Bahia: rito Nagô. $3^{\circ}$ ed. São Paulo: Nacional, 1978.

BIRMAN, Patrícia. Transas e transes: sexo e gênero nos cultos afro-brasileiros, um sobrevôo. Estudos feministas, Florianópolis, 13(2): 256, maio-agosto, 2005.

BRITO, Wesley Martins de. Os "Trabalhos" de cura na umbanda: Um ensaio etnográfico no “Terreiro Mina Nagô Cabocla Mariana e Tapinaré das Matas”, Igarapé-Açu, nordeste paraense. 2009. Trabalho de Conclusão de Curso (Ciências Sociais). Universidade do Estado do Pará: Igarapé-Açu, 2019.

BOURDIEU, Pierre. Sobre o Poder Simbólico In: O poder Simbólico. Trad. Fernando Tomas. Rio de Janeiro: Bertrand Brasil, 1989.

CAMPOS, Alessandro Ricardo Pinto. Cultura material dos terreiros: Um estudo sobre a coleção etnográfica afro-brasileira da Universidade Federal do Pará. Disertação (Mestrado). Universidade Federal do Pará. Instituto de Filosofia e Ciências Humanas. Programa de Pós-Graduação em Ciências Sociais, 2014.

CSORDAS, Thomas. Corpo/significado/cura. Porto Alegre: Editora UFRGS, 2008.

CRUZ, Ana Carolina Dias. Quantas cabeças tem Exu? Representações sociais sobre o povo de rua em terreiros de Umbanda no Rio de Janeiro, 2013. Tese (Doutorado em Psicologia) - Instituto de Psicologia, Universidade Federal do Rio de Janeiro, Rio de Janeiro, 2013.

DaMATTA, Roberto. Carnavais, paradas e procissões In: Carnavais, malandros e heróis: Para uma sociologia do dilema brasileiro. $6^{\circ}$ ed. Rio de Janeiro: Rocco, 1997.

. O ofício do etnólogo ou como ter "anthropological blues” In: NUNES, E. (Org.). A aventura sociológica. Rio de Janeiro: Zahar, 1981. 
DESLANDES, Suely Ferreira. O projeto de pesquisa como artesanato intelectual In: DESLANDES, Suely Ferreira; GOMES, Romeu; MINAYO, Maria Cecília de Souza (Org.). Pesquisa social: teoria, método e criatividade. $28^{\circ}$ ed. Petrópolis. RJ: Vozes, 2009, pp. 31-60

DOUGLAS, Mary. Pureza e perigo. Trad. Mônica Siqueira Leite Barros; Zilda Zakia Pinto. $2^{\circ}$ ed.: São Paulo: Editora Perspectiva, 2012.

ECKERT, Cornelia \& ROCHA, Ana Luiza da. Imagem recolocada: pensar a imagem como instrumento de pesquisa e análise do pensamento coletivo. Iluminuras, Rio Grande do Sul, v. 2, n. 3, 2001, pp. 2-13

ELIADE, Mircea. Mito e realidade. São Paulo: Editora Perspectiva, 1972.

EVANS-PRITCHARD, Evan E. Bruxaria, Oráculos e Magia entre os Azandes. Tradução Viveiro de Castro. Rio de Janeiro: ZAHAR, 2005.

FRY, Peter. Homossexualidade masculina e cultos afro-brasileiros In: Para Inglês Ver. Rio de Janeiro, ZAHAR, 1982, pp. 54-73.

Feijoada e soul food: Notas sobre a manipulação de símbolos étnicos e nacionais

In: Para inglês ver. Rio de Janeiro, ZAHAR, 1982, pp. 47-53.

GEERTZ, Clifford. Obras e vidas: o antropólogo como autor. Tradução: Vera Ribeiro. $4^{\circ}$ ed. Rio de Janeiro: Editora UFRJ, 2018.

LAGES, Sônia Regina Corrêa. Exu - luz e sombra. Uma análise psico-junguiana da linha de Exu na umbanda. Juiz de Fora: Clio Edições eletrônicas, 2003.

LE BRETON, David. A sociologia do corpo. $2^{\circ}$ ed. Tradução de Sônia M.S. Fuhrmann. Petrópolis, RJ: Vozes, 2007.

LÉVI-STRAUSS, Claude. Antropologia estrutural. Tradução: Beatriz Perrone-Moisés. São Paulo: Cosac Naify, 2008.

LOURO, Guacira Lopes (Org.). O corpo educado: Pedagogias da sexualidade. Tradução dos artigos: Tomaz Tadeu da Silva. Belo Horizonte: Autêntica, 2000.

LUCA, Taíssa Tavernard; NETO, Manuel V.; PANTOJA, Juscelino M. Catolicismo afro-amazônico: uma análise do simbolismo da morte na procissão do Senhor dos Passos em Belém/PA. OBSERVATÓRIO DA RELIGIÃO. Belém, v.3, n.1, 2016, pp. 49-75.

MARQUES, Roberto. Usos do som e instauração de paisagens sonoras nas festas de forró eletrônico. ILHA, v.13, n.2, jul./dez. 2012, pp.249-28.

MAUSS, Marcel. Sociologia e Antropologia. Tradução: Paulo Neves. São Paulo: Cosac \& Naify, 2003. 
MOTTA, Roberto. Le sacrifice, la table et la fête. Les aspects "néo-antiques" de la liturgie du candomblé brésilien. Paris, 1998.

NOVAES, Sylvia Caiuby. Entre a harmonia e a tensão: as relações entre antropologia e imagem. Revista Anthropológicas, ano 13, vol. 20, 2009, pp.9-26.

OLIVEIRA, Roberto Cardoso de. O Trabalho do antropólogo: olhar, ouvir e escrever In: O trabalho do antropólogo. São Paulo: Unesp, 2000.

PEREIRA, Anabela. Da corporeidade entre corpos: liminaridade vs continuum na performance. Estudos Aplicados, 2014, pp. 102-106.

PINTO, Tiago de Oliveira. Som e música: questões de uma antropologia. Revista USP, São Paulo, USP, v. 44, n.1, 2001, pp. 221-286.

PRANDI, Reginaldo. Exu, de mensageiro a diabo: sincretismo católico e demonização do Orixá Exu. REVISTA USP. São Paulo, n.50, junho/agosto 2001, p. 46-63.

Coração de Pombagira. Revista Esboços, Volume 17, n² 23, 2010, pp.141-149.

SILVA, Vagner Gonçalves da. Exu do Brasil: tropos de uma identidade afro-brasileira. Revista de antropologia, São Paulo, USP, v.55, n 12, 2012, pp. 1085-1114.

O antropólogo e sua magia: Trabalho de campo e texto etnográfico nas pesquisas antropológicas sobre religiões afro-brasileiras. $1^{\circ}$ ed., $2^{\circ}$ reimpressão - São Paulo: Editora da Universidade de São Paulo, 2015.

TRINDADE, Liana. Exu, poder e perigo. São Paulo. Ícone, 1985.

TURNER, Victor. O processo ritual: estrutura e anti-estrutura. Tradução de Nancy Campi de Castro. Petrópolis: Vozes, 1974.

VAN GENNEP, Arnold. Os ritos de passagem. 2. ed., Trad. Mariano Ferreira. Petrópolis: Vozes, 2011.

VERGER, Pierre Fatumbi. Lendas africanas dos Orixás. [ilustrações] Carybé; tradução Maria Aparecida da Nóbrega. $4^{\circ}$ ed. Salvador: Corrupio, 1997.

Orixás. Deuses Iorubás na África e no novo Mundo. $5^{\circ}$ ed. Salvador: Corrupio,

1999.

WAGNER, Roy. A invenção da cultura. Tradução Marcela Coelho de Souza e Alexandre Morales.

São Paulo: Cosac Naify, 2010. 